\title{
Społeczno-kulturowe mechanizmy funkcjonowania osoby transpłciowej
}

\begin{abstract}
Abstrakt: Ze względu na nietolerancję społeczną zachowań związanych z tożsamością płciową, większość osób transpłciowych doświadcza poważnego stresu na różnych etapach swojego życia. Aspekty relacji społecznych są istotne dla godnego i przyjaznego funkcjonowania dziecka transpłciowego w szkole i jego osiągnięć szkolnych, a następnie - już jako osoby dorosłej - ścieżek rozwoju zawodowego i podejmowania relacji społecznych. Podczas gdy niektóre szkoły i miejsca pracy oferują bezpieczne przestrzenie, wiele osób transpłciowych wciąż doświadcza negatywnych, wrogich i niebezpiecznych środowisk. Bez określonych działań mających na celu ochronę osób transpłciowych i szerzenie wiedzy na temat transpłciowości w społeczeństwie, większość osób o nienormatywnej tożsamości płciowej pozostaje podatna na dyskryminację, nękanie i zastraszanie. Dlatego tak ważne jest diagnozowanie trudności w funkcjonowaniu społecznym osób transpłciowych i wskazanie propozycji rozwiązań zmierzających do poprawy ich sytuacji w warunkach wykluczenia.
\end{abstract}

Słowa kluczowe: tożsamość płciowa, transpłciowość, tolerancja, dyskryminacja, społeczeństwo, wiedza

\section{Wstęp}

Problemem XXI wieku jest problem „odmienności”. Inny to termin, który nie tylko obejmuje wiele przejawów uprzedzeń na podstawie tożsamości grupowych, ale również ujawnia zestaw procesów i warunków propagujących nierówności i marginalizację. W tym kontekście definiujemy Inność jako zestaw procesów i struktur, które wywołują marginalność i utrzymującą się nierówność w całym zakresie różnic ludzkich w oparciu o tożsamość grupową (Powell i Menendian, 2016, ss. 14-40). Dotyczy to również różnych przejawów i wyrażania tożsamości płciowej, w tym transpłciowości.

Ludzka seksualność jest złożoną rzeczywistością, charakteryzującą się tożsamością płciową. Powszechnym podejściem do badania ludzkiej seksu- 
alności jest porównywanie grup o przeciwnej tożsamości płciowej, takich jak cispłciowe kontra transpłciowe (Frigerio i in., 2018). W tym aspekcie tożsamość płciowa to subiektywne, wewnętrzne poczucie bycia mężczyzną lub kobietą (lub inną kategorią płci), ustalone w chwili urodzenia lub w bardzo młodym wieku i mogące odbiegać od płci biologicznej danej osoby. Płeć jest czasem wyrażana w sposób, który ma niewielką lub żadną podstawę biologiczną (Mayer i McHugh, 2016, ss. 10-12). Najważniejszym zadaniem dla człowieka jest praca nad jego własną tożsamością, stanowiącą przejaw samorealizacji i wolności. Warunkiem tożsamości jest uznanie, czyli intersubiektywna relacja między ludźmi w sferze relacji intymnych (rodzina i bliscy), w sferze prawa (równość moralna i etyczna wszystkich członków społeczeństwa) i gospodarki (nierówności społeczne i rozwarstwienie charakteryzujące udział ludzi w wykorzystywaniu dóbr). Uznanie lub jego brak generuje odmienne praktyki społeczne i relacje z „innym”, konstruujące tożsamości. Doświadczenia stanowiące zagrożenie dla integralności ludzkiej tożsamości to przemoc fizyczna, pozbawienie praw i pogarda (Nowak-Dziemianowicz, 2018, ss. 167-182).

O osobach transpłciowych mówi się bardzo mało. Jest to temat bardzo rzadko poruszany społecznie. Tymczasem funkcjonowanie takiej osoby w codziennym życiu wiąże się często ze stresem, brakiem akceptacji, trudnościami w funkcjonowaniu szkolnym i zawodowym, a przede wszystkim brakiem wiedzy różnych środowisk i grup społecznych w zakresie transpłciowości. Zainteresowanie różnych grup społecznych tematem transpłciowości zaczyna się najczęściej dopiero w sytuacji, gdy w ich otoczeniu pojawi się osoba transpłciowa. Niewątpliwie zagadnienie transpłciowości jest tematem trudnym nie tylko w aspekcie medycznym, ale również - a może przede wszystkim - społecznym. W dużej mierze jego trudność w kontekście społecznym wynika z braku rzetelnej wiedzy i braku jej popularyzacji w społeczeństwie. Dlatego też celem niniejszego opracowania jest pogłębienie i upowszechnienie wiedzy o mechanizmach funkcjonowania osoby transpłciowej w społeczeństwie i kulturze. Tym bardziej że, jak podaje Dynarski (2011a, 2011b), literatura przedmiotu nie jest wolna od błędów i dezinformacji na temat osób transpłciowych, a transpłciowość jest problemem prawnoczłowieczym.

\section{Identyfikacja z własną płcią}

Osoby z dysforią płciową (GD; gender dysphoria; DSM-524) charakteryzują się niepokojem wynikającym z głębokiego poczucia niezgodności między 
płcią urodzeniową a odczuwaną (Bakker i in., 2016, ss. 395-404; Manson, 2008, ss. 16-21; Puts, 2008, ss. 100-111; Berenbaum i in., 2012, ss. 86-96). Tożsamość płciowa nie jest nabyta, pozostaje poza świadomym wyborem. Czasami natomiast tożsamość płciowa „zawodzi”, np. wśród osób transpłciowych postrzegających siebie jako urodzonych w niewłaściwej płci - w ich przypadku tożsamość płciowa nie koresponduje z ciałem. W takim kontekście, aby zrozumieć transpłciowość danej osoby, można dokonać podziału na płeć biologiczną i kulturową. Ciało zawsze należy do kogoś i mimo że zawsze uwikłane jest w znaczenia historyczne i kulturowe, to pojawia się w jego przypadku abstrakcyjny moment stanowiący kryterium jego przynależności do danej kategorii (kobieta/mężczyzna). Gender z kolei reprezentuje zależność danej osoby od kulturowych znaczeń tożsamości płciowej (Karlsson, 2015, ss. 381-407).

Zmuszenie dziecka do zachowania się w określony sposób nie zmieni jego tożsamości. Można oczywiście wpływać na jego zachowania zewnętrzne, ale jego poczucie tego, kim jest, raczej się nie zmieni. Wymuszanie zgodności płci może powodować depresję, niepokój, złe samopoczucie, a nawet myśli i próby samobójcze. Tożsamość płciowa nie jest wyuczonym ani wymuszonym zachowaniem; to subiektywne poczucie tego, kim jesteśmy od urodzenia. Taka sytuacja jest trudna. Postawa i poziom zaufania, które okazują w takiej sytuacji rodzice, często nadają ton temu, jak inni sobie poradzą $\mathrm{z}$ ujawnieniem tego faktu o dziecku. Ludzie boją się tego, czego nie rozumieją - istotne jest wobec tego zaprezentowanie na przykład najbliższej rodzinie artykułów czy książek, które pomogą im przyswoić informacje na temat tego, czym jest transpłciowość. Pierwsze reakcje nie zawsze są dobre. W tym aspekcie edukacja jest niezbędna. Niestety szkoła i inne organizacje edukacyjne bardzo często nie są zaznajomione ze stanem dziecka i wobec tego nie są w stanie zapewnić mu bezpiecznego środowiska. Tymczasem najważniejsze jest to, aby zapewnić dzieciom transpłciowym wsparcie i potwierdzić ich tożsamość (The American Academy of Pediatrics, 2018). Te same zasady dotyczą dorosłych osób transpłciowych. Dorosły często jeszcze silnej niż dziecko odczuwa swoją tożsamość płciową i jest jeszcze bardziej świadomy, że nie zmieni się ona pod wpływem nacisków społecznych. Wobec tego, tak samo jak w przypadku dziecka, dużym wsparciem w jego społecznym funkcjonowaniu są rodzina i najbliżsi. Niezbędne są tu również działania mające na celu uświadamianie ludziom (np. w środowisku zawodowym), czym jest transpłciowość. Istotne jest tu posługiwanie się naukową wiedzą, a nie potocznymi, często błędnymi przekonaniami. Również w przypadku dorosłych 
ludzi najważniejsza jest rzetelna edukacja mająca na celu przeciwdziałanie przemocy wobec osób transpłciowych.

Zgodnie z projektem noty ujawnionej w New York Times amerykański Departament Zdrowia i Opieki Społecznej (HHS; US Department of Health and Human Services) proponuje ustanowienie prawnej definicji tego, czy ktoś jest mężczyzną czy kobietą wyłącznie i niezmiennie na podstawie genitaliów, z którymi się rodzi. Mówi się, że testy genetyczne mogą być wykorzystane do rozwiązania wszelkich niejasności dotyczących wyglądu zewnętrznego. Zdaniem wielu środowisk taka propozycja nie ma podstaw naukowych i z pewnością cofnęłaby dziesięciolecia postępu w rozumieniu konstrukcji społecznej płci związanej z różnicami biologicznymi, ale również zakorzenionej w kulturze, normach społecznych i indywidualnych zachowaniach. Niektóre dowody sugerują, że tożsamość transpłciowa ma korzenie genetyczne lub hormonalne, ale jej dokładne biologiczne korelacje są niejasne. Bez względu na przyczynę organizacje takie jak American Academy of Pediatrics doradzają lekarzom, aby leczyli ludzi zgodnie z preferowaną płcią, niezależnie od wyglądu i genetyki. Społeczność naukowa i medyczna postrzega teraz płeć (sex) jako konstrukt bardziej złożony niż mężczyzna i kobieta, a płeć (gender) jako spektrum, które obejmuje między innymi osoby transpłciowe (Editorial in the Nature, 2018). Tym bardziej że jak podaje Jąderek (2016), zaburzenia identyfikacji płciowej dotyczą od 1\% do 3\% dzieci przed okresem dojrzewania, a 12-50\% dzieci przejawiających zaburzenia identyfikacji płciowej może rozwijać się w stronę tożsamości transpłciowej, co oznacza, że rodzice, nauczyciele, lekarze czy psychologowie nie są w stanie przewidzieć, w jakim kierunku będzie rozwijało się dziecko (Jąderek, 2016, ss. $11-20)$.

\section{Dyskryminacja a prawa osób transpłciowych}

Wykluczenie i dyskryminacja utrudniają osobom transpłciowym zarabianie pieniędzy, zachowanie bezpieczeństwa i realizację życiowych celów. Dyskryminacja ta przybiera różne formy, w tym odrzucanie przez rodzinę. Na całym świecie lista dyskryminujących praw i polityk jest ogromna, co wzmacniają negatywne postawy społeczne wobec społeczności transpłciowych. Obejmuje na przykład: wymaganie od osób transpłciowych poddania się przymusowej sterylizacji, zanim będą mogły zmienić płeć prawną; brak możliwości zmiany płci prawnej; zakazanie osobom transpłciowym tworzenia organizacji pozarządowych i publicznej kampanii na rzecz ich praw; wyłączanie osób 
trans z dostępu do mediów społecznościowych. Tymczasem ONZ wyjaśnia, że osobom transpłciowym należy zapewnić godność i prawa człowieka (Dorey i in., 2015). Dotyczy to również prawnej korekty płci w wielu krajach, w tym w Polsce. Na przykład Fundacja Trans-Fuzja walczy o wprowadzenie refundacji terapii hormonalnej i zabiegów korekty płci, przy czym w okresie pomiędzy 1991 a 2008 rokiem odbyło się w Polsce 245 postępowań sądowych dotyczących korekty płci metrykalnej (Dynarski, 2016). Z kolei badania przeprowadzone na przełomie 2012 i 2013 roku polegające na analizie akt sądowych dotyczących spraw o korektę płci wykazały, że w latach 2009-2013 (do marca) odbyły się 164 takie sprawy (Grzejszczak, 2013, ss. 11-73).

The Equality and Human Rights Commission podała, że dyskryminacja, molestowanie i stereotypizacja osób transpłciowych znacznie się zmniejszyły i są na dobrej drodze do wyeliminowania; osoby trans mają dobrą ochronę prawną, pracodawcy dobrze rozumieją ich obawy, a definicje prawne obejmują wszystkich, którzy określają się jako trans; polityka publiczna, w tym ochrona zdrowia i edukacja, zaspokajają potrzeby osób transpłciowych (Human Rights Campaigne, 2018a; Mitchell i Howarth, 2009). W rzeczywistości ci, którzy ujawniają swoją tożsamość płciową, doświadczają wyższego poziomu dyskryminacji w rodzinie, szkole, instytucjach opieki zdrowotnej, społecznej czy religijnej. Wielu nadal niechętnie ujawnia swoją tożsamość płciową w kontaktach z ludźmi. Problemy emocjonalne/psychiczne są nadal powszechne wśród osób transpłciowych, co często wpływa na ich zawodowe kariery, a członkowie rodzin wykazują bardzo często najniższy poziom akceptacji, odzwierciedlając tym samym presję społeczną (Mitchell i Howarth, 2009). Na przykład wśród niewłaściwych zachowań pracowników służby zdrowia osoby transpłciowe wymieniają nieetyczne przeprowadzenie lub odmowę wykonania badania, wskazywanie na zakażenie HIV, nieprzestrzeganie etyki lekarskiej i praw pacjenta do ochrony danych osobowych, odmowę przyjęcia do szpitala, obraźliwe komentowanie tożsamości płciowej, postawy moralizujące, molestowanie seksualne pacjenta (Abramowska i in., 2016).

Istnieją miejsca (na przykład Karaiby i znaczna część Afryki i Bliskiego Wschodu), dla których brak jest informacji na temat osób transpłciowych. Jednak na całym świecie osoby transpłciowe doświadczają piętna. Międzynarodowe badania udokumentowały łącznie 2115 zabójstw osób transpłciowych między styczniem 2008 roku a kwietniem 2016 roku, przy czym wiele innych zabójstw prawdopodobnie nie zostało zgłoszonych. Narodowe badanie australijskie wykazało, że u 56\% osób transpłciowych zdiagnozowano depresję w pewnym momencie ich życia, czterokrotnie więcej niż w po- 
pulacji ogólnej (Winter i in., 2016, ss. 390-400). Badanie U.S. Transgender Survey (USTS) z 2015 roku z udziałem 27715 respondentów ze wszystkich stanów USA, Dystryktu Kolumbii, Samoa Amerykańskiego, Guamu, Portoryko i amerykańskich baz wojskowych za granicą, wykazało, że 54\% osób transpłciowych doświadczyło prześladowania werbalnego, 24\% ataków fizycznych, 13\% napaści seksualnych, 29\% żyło w ubóstwie, a 40\% usiłowało popełnić samobójstwo. Doświadczenia respondentów wskazały jednak na rosnącą akceptację, np. 60\% zgłosiło wsparcie rodziny, 68\% wsparcie ze strony współpracowników, a 56\% uczniów wsparcie kolegów z klasy (James $\mathrm{i}$ in., 2016). W 2011 roku raport Injustice at Every Turn: A Report of the National Transgender Discrimination Survey wykazał, że nękanie, znęcanie się i dyskryminację zgłosiło 90\% ankietowanych, a 47\% zgłosiło zwolnienie lub odmowę awansu z powodu statusu osoby transpłciowej. Jednak pomimo dyskryminacji w dziedzinie medycyny, 76\% uczestników badania jest obecnie poddawanych terapii hormonalnej (Duggins, 2016).

W ostatnich latach społeczność międzynarodowa coraz bardziej zwraca uwagę na równe prawa mniejszości płciowych, a niektóre kraje uchwalają przepisy, które szanują i chronią ich prawa. Coraz częściej obserwuje się doniesienia o problemach osób transpłciowych w mediach. Niezastąpione okazują się również działania edukacyjne prowadzone przez organizacje społeczne. Coraz więcej organizacji pozarządowych i przedsiębiorstw zaczęło uznawać i chronić swoich transpłciowych pracowników. Te najlepsze praktyki mogą stanowić przesłankę i praktyczne pierwszeństwo dla przyszłych przepisów ustawowych, wykonawczych i polityk (United Nations Development Programme, 2016; Mitchell i Howarth, 2009).

Można uznać, że w Polsce dość dużo zmieniło się w tym aspekcie. Osoby transpłciowe, niezależnie od tego, czy dokonują tranzycji, czy nie, zaczynają być postrzegane jako te, którym powinno dawać się wsparcie, a nie jako osoby z zaburzeniami. Całość działań nadal koncentruje się jednak na dorosłych (Śledzińska-Simon, 2013, ss. 149-180). Biuro Rzecznika Praw Obywatelskich w 2013 roku podjęło próbę ogłoszenia przetargu na przeprowadzenie badań na temat sytuacji transpłciowych uczniów w szkołach. Działanie to spotkało się z ogromną i bardzo zróżnicowaną reakcją mediów (Dynarski, 2016, ss. 22-31). Badanie ECRI (Europejska Komisja przeciwko Rasizmowi i Nietolerancji) z 2014 roku przeprowadzone w Polsce wykazało, że Komisja pozytywnie oceniła zmiany wprowadzane w tym obszarze, ale mimo to nadal pozostaje niepokój związany z brakiem włączenia tożsamości płciowej do ochrony we wszystkich koniecznych przepisach. W związku z tym Komisja 
wydała zalecenie aby włączyć tożsamość płciową do dóbr chronionych w artykułach Kodeksu karnego oraz aby przeprowadzać badania na temat osób LGBT w Polsce pod kątem ich dyskryminacji i nietolerancji (Raport ECRI, 2015).

\section{Trudności dzieci i młodziézy transpłciowej w funkcjonowaniu w środowisku szkolnym}

Ze względu na aktualną nietolerancję społeczną większość dzieci z niestabilnością płciową doświadcza poważnego stresu. Wielu rodziców i krewnych wykazuje niewielką akceptację jakichkolwiek oznak dysforii ze względu na płeć, np. chłopcy, którzy z natury mają dziewczęcy wygląd i zachowania, są często poniżani przez rówieśników i członków rodzin. Zaburzenia tożsamości płciowej są związane ze zwiększonym ryzykiem wykorzystywania fizycznego lub seksualnego oraz stresem pourazowym u młodzieży. Ważne jest, aby właściwie zbadać te kwestie podczas badania dziecka z problemami tożsamości płciowej. Niestety liczba uczestniczących we wszystkich takich badaniach jest zbyt mała, aby można było sformułować jakiekolwiek rozstrzygające stwierdzenia (Ghosh, 2015, ss. 16-17).

Podczas gdy w niektórych szkołach oferuje się bezpieczne przestrzenie umożliwiające rozkwit młodzieży z zaburzeniami tożsamości płciowej, wielu młodych ludzi wciąż doświadcza negatywnych, wrogich i niebezpiecznych środowisk szkolnych. Bez ogólnokrajowych polityk mających na celu ochronę transpłciowych uczniów lub kompleksowych szkoleń integracyjnych, większość tych młodych ludzi pozostaje podatna na dyskryminację, nękanie i zastraszanie ze strony rówieśników, nauczycieli i personelu szkoły (James i in., 2016). W 2017 roku Human Rights Campaigne (HRC) wraz z badaczami z University of Connecticut przeprowadzili ankietę wśród 5600 młodych transpłciowych ludzi - wykazano, że: $72 \%$ z nich informuje, że ich rodziny negatywnie komentują osoby LGBTQ; 69\% doświadczyło niechcianych komentarzy, żartów i gestów; 42\% spotkało się z zagrożeniami fizycznymi ze względu na swoją tożsamość; tylko 16\% zawsze czuje się bezpiecznie w szkole; 51\% nigdy nie korzysta w szkole z toalet, które są zgodne z ich tożsamością płciową; młodzież transpłciowa jest $\mathrm{z}$ dwa razy bardziej narażona na napaści seksualne lub gwałty niż rówieśnicy cispłciowi oraz ma problemy ze snem w nocy (Human Rights Campaigne, 2018a). Ponad 70\% zgłosiło poczucie bezwartościowości w każdym tygodniu, a tylko 5\% twierdzi, że wszyscy nauczyciele i pracownicy szkoły wspierają ich (Human Rights Campaigne, 
2018b). Badanie U.S. Transgender Survey (USTS) z 2015 roku wykazało, że aż $17 \%$ spotkało się z tak poważnym złym traktowaniem z powodu bycia osobą transpłciową, że opuściło szkołę (James i in., 2016). Obserwacje nastolatków transpłciowych sugerują znaczne trudności w relacjach rówieśniczych, znaczące złe doświadczenia związane z prześladowaniem, okresy izolacji społecznej w dzieciństwie i okresie dojrzewania (Riittakerttu, 2018). Raport Suicide Attempts among Transgender and Gender Non-Conforming Adults z 2014 roku podał, że 45\% osób transpłciowych w wieku 18-44 lat w USA podjęło przynajmniej jedną próbę samobójczą. Badanie nie uwzględniło osób niepełnoletnich, ale można przypuszczać, że odsetek podobnych przypadków byłby podobny lub większy. Przenosząc to na grunt Polski, na którym brak jej danych statystycznych w tym zakresie, można przyjąć, że dane nie będą znacząco różne, mimo że Polska i USA różnią się pod względem polityki wyrównywania szans różnych grup społecznych (Dynarski, 2016, ss. 22$-31)$.

Znęcanie się nad dziećmi transpłciowymi w szkole może przyczyniać się do rozwoju lęku i objawów depresyjnych. Uczucia takie, jak samotność i poczucie odmienności, mogą prowadzić do samookaleczeń, impulsywności lub prób samobójczych czy angażowania się w niezdrowe zachowania (Aitken i in., 2016, ss. 513-520). Silnie wsparcie dzieci transpłciowych przez rodziców wiąże się z wieloma pozytywnymi skutkami dla ich zdrowia psychicznego (Le i in., 2016). Aby pomóc, należy przedyskutować całe spektrum możliwości. Niektórzy psychologowie oferują leczenie behawioralne. Niestety, jeśli anatomia mózgu jest naprawdę kluczowym czynnikiem w tożsamości płciowej, terapia behawioralna zaprojektowana w celu zmiany odczuć i przekonań poznawczych prawdopodobnie nie jest optymalna. Natomiast dzięki większej świadomości, tolerancji i akceptacji tych osób - jako części społeczeństwa - niektóre nastolatki są w stanie postawić pierwsze kroki, przechodząc do zgodności płci z interwencjami medycznymi lub bez nich. W każdym przypadku konieczna jest dogłębna ocena tożsamości płciowej, preferowanej roli płciowej i pełnej historii psychospołecznej w celu oceny sytuacji (Ghosh, 2015, ss. 16-17). Badania przeprowadzone przez Grzejszczaka i Krzywdzińską wykazały, że wyższy zakres wiedzy na temat transpłciowości jest skorelowany z osobami z młodszego pokolenia; istnieje tendencja do większej akceptacji osób transpłciowych w kontekście wykonywanych przez nich zawodów u osób z pokoleń młodszych; im niższy wiek respondentów, tym większa zgoda na wykonywanie przez osoby transpłciowe zawodów związanych z przebywaniem z dziećmi; niezależnie od grupy pokoleniowej 
respondenci uznali, że gdyby ktoś z ich bliskich okazał się być transpłciowy, to nie zmieniliby stosunku do niego. Różnice generacyjne w zakresie postrzegania zagadnień z zakresu transpłciowości dają nadzieję, że działania na rzecz depatologizacji tego zjawiska wpływają pozytywnie na zmiany postaw (Grzejszczak i Krzywdzińska, 2013, ss. 227-262). Ponadto Fundacja Trans-Fuzja podaje, że młodzież transpłciowa otrzymuje dużo większą akceptację w szkole niż w systemie medycznym i terapeutycznym. Jednak ze względu na bardzo nieliczną reprezentację tych osób trudno jest w jakikolwiek sposób generalizować doświadczenia całej grupy społecznej (Dynarski, 2016).

Rozwój zawodowy nauczyciela w zakresie wiedzy na temat problemów uczniów z zaburzeniami tożsamości płciowej ma kluczowe znaczenie. Zapewnianie nauczycielom szkoleń na temat rozumienia płci i powstrzymywania znęcania się na tle płciowym jest ważnym działaniem dyrekcji szkół. Istotne jest uwzględnianie rzeczywistej tożsamości płciowej uczniów, tworzenie przyjaznego środowiska edukacyjnego między innymi poprzez organizację zajęć o tematyce dotyczącej stereotypów płciowych, aby pomóc im zrozumieć płciowość człowieka (Human Rights Campaigne, 2018b). Mając w klasie uczniów z zaburzeniami tożsamości płciowej, należy upewnić się, że są oni bezpieczni. Sprzyja temu budowanie silnego poczucia wspólnoty i akceptacji w klasie i szkole (Human Rights Campaigne, 2018c). Znajomość zagadnień płci zapewnia uczniom umiejętność posługiwania się właściwym językiem w zakresie płciowości i dojrzewania płciowego. Tym bardziej że uczniowie dostrzegają dzieci, które angażują się w działania wykraczające poza stereotypy dotyczące płci (Gender Spectrum, 2019). Raport Transptciowa młodzież $w$ polskiej szkole wykazał, że w Polsce brakuje regulacji prawnych i programów edukacyjnych na temat transpłciowości. Mimo to nauczyciele i dyrektorzy tworzą godne warunki edukacyjne i rozwojowe swoim transpłciowym uczniom, zazwyczaj bez wsparcia kuratorium i z obawą o utratę pracy, oraz zaczynają szkolić się w tym zakresie (Dynarski i in., 2016).

\section{Problemy zawodowe osób transpłciowych}

Osoby transpłciowe nadal doświadczają ograniczonych możliwości, dyskryminacji i nękania w miejscu pracy pomimo istnienia przepisów antydyskryminacyjnych. Znajdują się one na stanowiskach poniżej swoich umiejętności i zdolności, niskoopłacanych i niepewnych. Niektóre osoby transpłciowe nie chcą przejść operacji korekty płci z obawy przed wykluczeniem w pracy (Mitchell i Howarth, 2009). 
Badania U.S. Transgender Survey (USTS) z 2015 roku wykazały, że stopa bezrobocia wśród osób transpłciowych (15\%) była trzykrotnie wyższa niż stopa bezrobocia w całej populacji USA (5\%). Jeden na sześciu respondentów zgłaszał utratę pracy lub odmówienie awansu z powodu tożsamości płciowej, a $19 \%$ nie zostało zatrudnionych z tego powodu. Z kolei $15 \%$ było ustnie nękanych, atakowanych fizycznie lub seksualnie, a 23\% zgłosiło inne formy maltretowania ze względu na tożsamość płciową. Aż 77\% respondentów, którzy mieli pracę, w celu uniknięcia złego traktowania ukrywało swoją transpłciowość (James i in., 2016). W innych badaniach wykazano, że ludzie, którzy nie planują zmiany płci, otrzymują niewielką lub żadną ochronę. Wielu pracodawcom brakuje polityk antydyskryminacyjnych dotyczących tożsamości płciowej, pomimo istnienia szeregu poradników najlepszych praktyk (Mitchell i Howarth, 2009). Kiedy porównano osoby transpłciowe z ich nietranspłciowym rodzeństwem, stwierdzono, że nawet gdy są one lepiej wykształcone, nie osiągają odpowiedniego wzrostu dochodów (Factor i Rothblum, 2007, ss. 11-30).

Whittle i in. (2007) zauważają, że przepisy z 2005 roku dotyczące równości zatrudnienia (dyskryminacji seksualnej) w Wielkiej Brytanii zabraniają pracodawcom tworzenia wrogiego środowiska dla osób trans. Pojawia się również coraz więcej organizacji, takich jak na przykład Micro Rainbow International (MRI), która działa na rzecz walki z ubóstwem osób LGBTI na całym świecie. Zapewniają one mentoring, szkolenie umiejętności i coaching, oraz ułatwiają zakładanie małych firm osobom transpłciowym. Okazuje się również, że coraz częściej osoby transpłciowe, które są w stanie wnieść wkład w gospodarstwo domowe, są bardziej akceptowane społecznie i w rodzinach (Dorey i in., 2015).

Raport z polskich badań zrealizowanych w 2015 roku na zlecenie Rzecznika Praw Obywatelskich wykazał, że brak zrozumienia transpłciowości i negatywne stereotypy w tym zakresie mają związek z niskim poziomem akceptacji społecznej wykonywania przez osoby transpłciowe różnych profesji, np. aż 65\% Polaków nie zaakceptowałoby osoby transpłciowej jako opiekuna swojego dziecka, 64\% jako nauczyciela swojego dziecka, 59\% jako lekarza, 51\% jako prawnika, 50\% jako urzędnika państwowego. Z kolei 40\% zaakceptowałoby osobę transpłciową jako współpracownika, ale aż 52\% uznało, że polscy pracodawcy nie chcieliby zatrudnić osoby transpłciowej; $67 \%$ jest świadomych, że osoby transpłciowe doświadczają trudności w poszukiwaniu pracy; $49 \%$ jest zdania, że używanie w stosunku do osoby transpłciowej imienia odpowiadającego jej tożsamości płciowej nie powinno być akceptowane w miejscu 
pracy; 44\% uznało, że nie jest konieczne informowanie współpracowników przez osobę transpłciową o swojej tożsamości płciowej (Biuletyn Rzecznika Praw Obywatelskich, 2016). Raport wykazał, że zdecydowana większość Polaków nie zna nawet jednej transpłciowej osoby i nie ma wiedzy z obszaru transpłciowości. Wskazuje to na potrzebę przeprowadzenia badań i uzyskania danych na temat osób transpłciowych oraz ich dyskryminacji i nietolerancji wobec nich (Siostrzonek-Sergiel, 2017, ss. 251-265).

\section{Osoby transpłciowe w społeczeństwie, kulturze i mediach}

Dla osób transpłciowych piętnem społecznym jest przekonanie ogólnej populacji, że osoba o nienormatywnej tożsamości płciowej nie jest w stanie pełnić niektórych ról w społeczeństwie, na przykład być dobrym pracodawcą, studentem, najemcą, członkiem rodziny lub obywatelem (Park, 2016). Morton (2008) podał, że 62\% respondentów doświadczyło w miejscach publicznych prześladowania transfobicznego - przeważnie przybrało to formę znęcania werbalnego, ale 40\% doświadczyło zachowań zagrażających zdrowiu, $17 \%$ zostało napadniętych fizycznie, a 4\% doświadczyło napaści seksualnej. Ponadto, pomimo wysokich wskaźników przestępstw z nienawiści, wysoki ich odsetek nie jest zgłaszany z obawy przed negatywnymi konsekwencjami ujawnienia tożsamości płciowej oraz brakiem pewności sprawiedliwego potraktowania przez policję. Stwierdzono, że policja ma małą wiedzę i pewność w kontaktach z osobami trans, co sugeruje potrzebę szkolenia i przekazywania im wskazówek dotyczących dobrych praktyk w tym zakresie (Mitchell i Howarth, 2009).

Istnieje ogólna zgoda badaczy co do tego, że osoby transpłciowe są bardziej zagrożone - w porównaniu z populacją ogólną - wieloma problemami zdrowia psychicznego. W literaturze naukowej dominującym wyjaśnieniem jest model stresu społecznego, który zakłada, że stresory społeczne, takie jak stygmatyzacja i dyskryminacja, napotykane przez członków tej subpopulacji przyczyniają się do rozbieżności w wynikach zdrowia psychicznego (Mayer i McHugh, 2016, ss. 10-12). Implikacją modelu stresu społecznego jest to, że zmniejszenie tych stresów poprawiłoby sytuację (Hatzenbuehler, 2009, ss. 707-730; Graham i in., 2011). Badanie przeprowadzone w 2013 roku przez psychologa z Columbia University Waltera Bocktinga i jego współpracowników wśród 1.093 osób transpłciowych wykazało dodatnią korelację między cierpieniem psychicznym a odczuwanym piętnem (Bockting i in., 2013, ss. 943-951), które może wpływać na decyzje osób transpłciowych 
o ukrywaniu prawdy o sobie w obawie przed dyskryminacją, poczuciem wstydu lub potencjalnym konfliktem między ich rolą społeczną a pragnieniami, szczególnie w szkole i pracy (Mayer i McHugh, 2016).

Idea, że nauka może wyciągać ostateczne wnioski na temat sex lub gender, jest zasadniczo błędna. Na przykład organizacje takie jak Międzynarodowy Komitet Olimpijski (MKOl) borykają się z tym od dziesięcioleci. W latach 60. XX wieku, obawiając się, że mężczyźni będą rywalizować w zawodach kobiecych, urzędnicy próbowali klasyfikować sportowców poprzez badania narządów płciowych - proces nachalny i upokarzający. Testy DNA sprawdzające obecność chromosomu Y również nie okazały się wiarygodne: osoby z chromosomami XY mogą mieć cechy żeńskie ze względu na warunki, w tym niezdolność do odpowiedzi na testosteron. Obecnie MKOl klasyfikuje sportowców, mierząc ich poziom testosteronu, ale i to jest wadliwe (Editorial in the Nature, 2018).

Osoby transpłciowe mogą również napotkać wyjątkowe uprzedzenia w opiece zdrowotnej. Rezultaty badań ankietowych przeprowadzonych wśród 6000 transpłciowych Amerykanów wskazują, że 19\% respondentom odmówiono opieki zdrowotnej z powodu ich statusu transpłciowego, przy czym dodatkowe $28 \%$ przełożyło konieczną opiekę zdrowotną w przypadku choroby lub urazu, a 33\% nie szukało już opieki profilaktycznej z powodu upokorzenia (śmiech, wskazywanie, żarty, drwiny, kpiny, obelgi i szeroka gama negatywnych komentarzy, naruszenie poufności, użycie niewłaściwego zaimka wobec pacjenta, wyjątkowo długie oczekiwanie na opiekę, niepotrzebne oglądanie narządów płciowych, nieprzestrzeganie standardów opieki) (Lambda Legal i in., 2016). Z tych powodów osoby te często korzystają z usług pozamedycznych lub pseudomedycznych i biorą udział w niemonitorowanym leczeniu hormonalnym (Winter i in., 2016, 390-400). Na szczęście istnieje coraz więcej instytucji, takich jak na przykład UCSF Center of Excellence for Transgender Health, które formułują wytyczne dotyczące podstawowej opieki zdrowotnej i klinicznej oraz organizują szkolenia w zakresie kompetencji kulturowych. Pojawia się coraz więcej internetowych seminariów, które mają na celu przeciwdziałanie szerzeniu się niewiedzy na temat transpłciowości (Human Rights Campaign, 2019; Lambda Legal i in., 2016).

W całej historii i wielu kulturach, od wieków istniały osoby o tożsamościach, które współcześnie nazywamy trans (Eisfeld i in., 2013). Wiele społeczeństw oferuje płynny i elastyczny portret tożsamości płciowej, np. hidźra stanowiącą trzecią kategorię płciową w Indiach, będącą kilkumilionową społecznością o ciałach męskich lub interseksualnych, ale nie utożsamiającą 
się z rolą męską i odgrywającą w społeczeństwie nie do końca definiowaną kulturowo rolę; two-spirit występujący w rdzennych ludach Ameryki Północnej i cieszący się najwyższym plemiennym statusem społecznym; muxe, czyli współcześnie występujące $\mathrm{w}$ meksykańskim stanie Oaxaca osoby urodzone w męskich ciałach, lecz pełniące w społeczeństwie odmienną niż męska i żeńska rolę; kathoey stanowiące społeczność w kulturze tajskiej; zaprzysiężone dziewice występujące w Albanii, którym patriarchalne społeczeństwo nadawało pełnię praw społecznych przysługujących jedynie mężczyznom, jeśli przyjęły one męską rolę płciową i publicznie zadeklarowały, że będą żyły w celibacie (Bojarska i Kłonkowska, 2014, ss. 63-82). Istnieją również yan daudu (Nigeria), fa'afafine (Samoa), fakaleiti (Tonga), acault (Birma), bissu (Indonezja), guevedoce (Republika Dominikany), czy mahu (Hawaje) (Dunn, 2018). Najbardziej znanym przypadkiem w literaturze etnograficznej jest tak zwany berdache, występujący w wielu społeczeństwach rdzennych w Ameryce Północnej i przyjmujący role płciowe przeciwne do płci anatomicznej (Robertson, 2005). Khanith występujący w Omanie to męskie prostytutki homoseksualne, których ubiór jest męski, ale maniery żeńskie i które mogą spotykać się z kobietami, mają własne gospodarstwa domowe, wykonują zadania męskie i żeńskie, jak również mogą poślubić kobiety, udowadniając swoją męskość poprzez skonsumowanie małżeństwa (Wikan, 2013). W muzułmańskiej społeczności Indonezji istnieją waria uczestniczący w życiu publicznym, religijnym, kulturalnym i szerzący wiedzę na temat zdrowia w ramach edukacji seksualnej, ale mimo to nie znajdujący społecznej akceptacji (Jamrozik, 2012, ss. 132-135).

Młodzi ludzie są bardziej otwarci na różnorodność płciową. Zmiana pokoleniowa stanowi największą szansę na społeczną emancypację osób transpłciowych. Praktycznie, aby osiągnąć ten cel, potrzebna jest szersza i intensywniejsza edukacja oraz informacje oparte na dowodach. W szkole i pracy edukacja i szkolenia w zakresie różnorodności płci są nadal rzadkie i rozproszone. Gdyby stały się bardziej rozpowszechnione, dwuznaczność niektórych treści z zakresu tożsamości płciowej zostałaby wyeliminowana. W tym względzie media głównego nurtu mają również do odegrania ważną rolę (United Nations Development Programme, 2016).

We wczesnych latach 50. XX wieku wokół transpłciowych „mężczyzn i kobiet pojawiły się szumy medialne, a pomysły na ich temat stały się częścią krajobrazu kulturowego. Coraz więcej osób zaczęło kontaktować się z ekspertami medycznymi, aby poprosić o rozpoczęcie procedury zmiany płci, o której słyszeli w mediach. Procedury zmieniające ciało były dostępne, ale w bardzo 
małej liczbie i wykonywane były przez niewielu praktyków. Wielu innych specjalistów opowiadało się za leczeniem umysłu zamiast ciała" (Bryant, 2006, ss. 23-39). W ostatnich latach zmieniło się nieco postrzeganie osób transpłciowych przez społeczeństwo, a osoby takie jak Caitlyn Jenner i Laverne Cox stają się rozpoznawalnymi twarzami zmarginalizowanej populacji. Prawa osób transpłciowych stały się również jednym z głównych zagadnień politycznych (Williams, 2018). Na przykład kandydaci transpłciowi są wybierani na urzędy publiczne, a telewizja i filmy zwykle przedstawiają postacie LGBTQ w pozytywnym świetle. Te znaczące zmiany kulturowe i osiągnięcia to kamienie milowe dające nadzieję wielu osobom z zaburzeniami tożsamości płciowej na normalne życie w społeczeństwie (Human Rights Campaigne, 2018b).

Polskie organizacje pozarządowe działające na rzecz osób LGBTQIA (skrót oznaczający lesbijki, gejów, osoby biseksualne, transpłciowe, queer, interpłciowe oraz aseksualne) od ponad 10 lat intensywnie starają się o wprowadzenie zmian dotyczących sytuacji osób transpłciowych w zakresie dostępu do usług zdrowotnych, regulacji ułatwiających uzgodnienie płci w szybki i przejrzysty sposób dostosowania zabiegów korekty płci i terapii hormonalnej do potrzeb tranzycyjnych i ubezpieczenia zdrowotnego, a także konieczności uaktualnienia standardów diagnostyki. Można uznać, że w Polsce dość dużo zmieniło się w tym aspekcie. Osoby transpłciowe, niezależnie od tego, czy dokonują tranzycji czy nie, zaczynają być postrzegane jako te, którym powinno dawać się wsparcie, a nie jako osoby zaburzone. Całość działań nadal koncentruje się jednak na osobach dorosłych. Pomoc młodym ludziom transpłciowym bardzo często jest utrzymywana w tajemnicy. Wynika to ze strachu przed odrzuceniem i przemocą. Nie ma również odpowiednich regulacji z zakresu zapewniania bezpieczeństwa niepełnoletnim osobom transpłciowym, np. w szkole czy grupach rówieśniczych (Śledzińska-Simon, 2013, ss. 149-180; Dynarski, 2016, ss. 22-31).

\section{Podsumowanie}

Rozumienie rozróżnienia między płciami jest bardziej zakorzenione w przekonaniach społecznych niż w biologii. Nastawienie do danego problemu leży u podstaw zarówno przedsięwzięcia naukowego, jak i otwartości społeczeństwa (Foht, 2015, ss. 127-137). Aspekty relacji społecznych są istotne dla dobrego samopoczucia w szkole, wyników edukacyjnych i ścieżek rozwoju zawodowego. Uznanie naturalnej zmienności pozwala młodym ludziom akceptować siebie i innych takimi, jakimi są. Jeden z najtrudniejszych aspek- 
tów dojrzewania to chęć poczucia absolutnej pewności, że jest się zupełnie „normalnym” pod względem rozwoju płciowego. Tymczasem młodzież transpłciowa doświadcza zastraszania i dyskryminacji w szkołach, nie tylko przez rówieśników, ale nawet przez nauczycieli; w związku z tym postrzega szkoły jako miejsca niebezpieczne. Wiktymizacja związana z płcią może obniżać wyniki w nauce, a rezygnacja ze szkoły jest silnie związana z wykluczeniem społecznym. Dlatego istotne jest, aby na lekcjach dotyczących płciowości człowieka rozmawiać z uczniami na temat szerokiego zakresu norm, a nie sztywnych schematów rozwoju.

Dorosłe osoby transpłciowe również napotykają na wiele trudności. Pomimo prawnej ochrony przed dyskryminacją w zatrudnieniu, nadal doświadczają dyskryminacji w pracy. Są również narażone na większe ryzyko gorszego statusu społeczno-ekonomicznego, co wiąże się ze zwiększonym bezrobociem lub zatrudnieniem na niskim poziomie płacowym. Istotną rolę mogą tu odgrywać cechy społeczno-kulturowe związane z tolerowaniem określonych tożsamości płciowych. Ponadto osoby transpłciowe napotykają wiele barier w otrzymaniu opieki zdrowotnej. Niestety wiele z nich unika kontaktu z lekarzem w obawie przed dyskryminacją, poniżaniem lub niezrozumieniem. A przecież personel medyczny pierwszej linii odgrywa kluczową rolę w tworzeniu środowiska opieki. W przypadku młodych osób transpłciowych to rodzice zajmują pierwsze miejsce w kontekście rozumienia i pomocy, drugie zaś specjalista medyczny - to stawia lekarzy w niezwykle ważnej pozycji.

Mimo tak wielu przeciwności w funkcjonowaniu społecznym osób transpłciowych wzrasta świadomość w zakresie transpłciowości oraz widoczne jest coraz mniejsze piętno społeczne. Na przykład wiele osób dokumentuje historie swojego „przejścia” na YouTube, aby służyć innym poradą na bazie swoich osobistych doświadczeń. Grupy wsparcia dla osób transpłciowych mogą być również bardziej dostępne za sprawą Internetu, przez co stanowią bardziej dostępne źródło wzajemnej pomocy i informacji.

Problem Inności wymyka się łatwym odpowiedziom. Jedynym realnym rozwiązaniem jest włączenie i przynależność, co pociąga za sobą niezachwiane zobowiązanie, by nie tylko tolerować i szanować różnicę, ale także dbać o to, aby wszyscy ludzie czuli, że należą do społeczeństwa. Nazywamy to „kręgiem ludzkiej troski”. Poszerzenie kręgu wiąże się z „humanizowaniem drugiego”, w którym negatywne reprezentacje są kwestionowane i odrzucane. Integracja jest konieczna, ale nie zawsze wystarczająca. Oprócz zabezpieczeń strukturalnych potrzebujemy wizji społeczeństwa obejmującej nowe tożsamości i narracje, które odciągają od demagogii i demonizacji Innych. Jedną z możliwych 
alternatyw dla „akulturacyjnych” strategii asymilacji, integracji, separacji lub marginalizacji są "głos” i „dialog” (Powell i Menendian, 2016, ss. 14-40).

\section{Bibliografia}

Abramowska, M., Bojarska, K., Chaber, A., Dynarski, W., Hunt, R., Jąderek, I., Kowalczyk, R., Krupka-Matuszczyk, I., Krzystanek, M., Loewe, A., Mazurczak, A., Rodzinka, M., Rogowska-Szadkowska, D. i Sady, F. 2016. Zdrowie LGBT. Przewodnik dla kadry medycznej. Warszawa: KPH.

Aitken, M., VanderLaan, D.P., Wasserman, L., Stojanovski, S. and Zucker, K.J. 2016. Selfharm and suicidality in children referred for gender dysphoria. Journal of the American Academy of Child E Adolescent Psychiatry. 55, pp. 513-520.

Bakker, J., Burke, S., Kreukels, B., Cohen-Kettenis, P., Veltman, D. and Klink, D. 2016. Male-typical visuospatial functioning in gynephilic girls with gender dysphoria - organizational and activational effects of testosterone. Journal of Psychiatry \& Neuroscience. 41, pp. 395-404.

Berenbaum, S., Bryk, K. and Beltz, A. 2012. Early androgen effects on spatial and mechanical abilities: evidence from congenital adrenal hyperplasia. Behavioral Neuroscience. 126, pp. 86-96.

Bockting, W., Miner, M., Swinburne Romine, R., Hamilton, A. and Coleman, E. 2013. Stigma, Mental Health, and Resilience in an Online Sample of the US Transgender Population. American Journal of Public Health. 103 (5), pp. 943-951.

Bojarska, K. i Kłonkowska, A. 2014. Transgresja płci, tranzycja ciała, transwersja tożsamości. Czym jest transpłciowość? W: Kłonkowska, A. i Bojarska, K. red. Psychospołeczne, prawne i medyczne aspekty transptciowości. Gdańsk: UG, ss. 63-82.

Bryant, K. 2006. Making Gender Identity Disorder of Childhood: Historical Lessons for Contemporary Debates. Sexuality Research and Social Policy: Journal of NSRC. 3 (3), pp. 23-39.

Dorey, K., O'Connor, J. and Long, A. 2015. The Sustainable Development Goals And LGBT Inclusion. London: Stonewall Equality Limited.

Duggins, K.L. 2016. Student Attitudes Toward the Transgender Community Following Restroom Reassignment, OTS Master's Level Projects \& Papers, 426. Old Dominion University, Graduate Faculty, approved by: P.A. Reed, J.M. Ritz. https://digitalcommons.odu.edu/ots_masters_projects/426 (16.07.2020). 
Dunn, P.R. 2018. The Conditions for Obtaining Legal Gender Recognition: A Human Rights Evaluation. Bristol: University of Bristol Law School.

Dynarski, W. 2011a. Tematyka transpłciowości w wybranych publikacjach oraz jej usytuowanie we wspótczesnych dyskursach akademickich. Warszawa: Fundacja Trans-Fuzja.

Dynarski, W. 2011b. Analiza wybranych badań nad ptciowościa Piotra Wtasta $z$ perspektywy transgender studiem. Praca magisterska napisana pod kierunkiem dr. hab. Jana Potkańskiego. Warszawa: Uniwersytet Warszawski, Wydział Polonistyki.

Dynarski, W. 2016. Gdy system nie ma nic do zaoferowania. Potrzeby transpłciowej młodzieży w Polsce i sprostanie im. W: Dynarski, W., Jąderek, I. i Kłonkowska, A.M. red. Transptciowa młodzież w polskiej szkole, Raport z badań. Gdańsk: UG, ss. 22-31.

Dynarski, W., Jąderek, I. i Kłonkowska, A.M. red. 2016. Wstęp. Transptciowa młodzież w polskiej szkole. Raport z badań. Gdańsk: UG, ss. 7-9.

Editorial in the Nature. 2018. Anatomy does not define gender. US proposal for defining gender has no basis in science. Nature. 563, pp. 5-6.

Eisfeld, J., Gunther, S. and Shlasko, D. 2013. The State of Trans* and Intersex Organizing: A case for increased support for growing but under-funded movements for human rights. New York: Global Action for Trans* Equality and American Jewish World Service.

Factor, R. and Rothblum, E. 2007. A study of transgender adults and their non-transgender siblings on demographic characteristics, social support, and experiences of violence. Journal of LGBT Health Research. 3, pp. 11-30.

Foht, B. 2015. Socially Just Science. The New Atlantis. 45, pp. 127-137.

Frigerio, A., Ballerini, L. and Valdés Hernández, M. 2018. Structural, functional and metabolic brain differences between groups with opposite gender identity and sexual orientation. A systematic review on the neuroimaging literature up to 2018, 2004-2018 [dataset]. Edinburgh: University of Edinburgh, College of Medicine and Veterinary Medicine, School of Clinical Sciences, Centre for Clinical Brain Sciences.

Gender Spectrum. 2019. Understandings gender. Resources for Parents and Caregivers. We can help. Explore topic. Medical. Mental health. San Leandro, CA: The Child \& Adolescent Gender Center (CAGC).

Ghosh, S. 2015. Gender Identity. Medscape. 3, pp. 16-17.

Graham, R. 2011. Committee on Lesbian, Gay, Bisexual, and Transgender Health Issues and Research Gaps and Opportunities i Institute of Me- 
dicine. The Health of Lesbian, Gay, Bisexual, and Transgender People: Building a Foundation for Better Understanding. Washington, D.C: The National Academies Press.

Grzejszczak, R. 2013. Transpłciowość w świetle badań. W: Dynarski, W. i Śmiszek, K. red. Sytuacja prawna osób transptciowych $w$ Polsce. Raport $z$ badań i propozycje zmian. Warszawa: Fundacja Trans-Fuzja, Polskie Towarzystwo Prawa Antydyskryminacyjnego, ss. 11-73.

Grzejszczak, R. i Krzywdzińska, A. 2013. Społeczne spostrzeganie. W: Dynarski, W. i Śmiszek, K. red. Sytuacja prawna osób transptciowych w Polsce. Warszawa: Polskie Towarzystwo Prawa Antydyskryminacyjnego, ss. 227-262 .

Hatzenbuehler, M. 2009. How Does Sexual Minority Stigma 'Get Under the Skin’? A Psychological Mediation Framework. Psychological Bulletin. 135 (5), pp. 707-730.

Human Rights Campaigne. 2018a. Gender-Expansive Youth Report. Washington: Human Rights Campaign Foundation.

Human Rights Campaigne. 2018b. LGBTQ Youth Report. Washington: $\mathrm{Hu}-$ man Rights Campaign Foundation.

Human Rights Campaigne. 2018c. Affirming Gender in Elementary School: Social Transitioning, Welcoming School: A Project of HRC. Washington: Human Rights Campaign Foundation.

Human Rights Campaign. 2019. Transgender Patient Services E Support: Resources for Providers and Hospital Administrators, Health \& Aging, Transgender. Washington: Human Rights Campaign Foundation.

James, S., Herman, J., Rankin, S., Keisling, M., Mottet, L. and Anafi, M. 2016. Executive Summary of the Report of the 2015 U.S. Transgender Survey. Washington, DC: National Center for Transgender Equality.

Jamrozik, I. 2012. Waria w muzułmańskim społeczeństwie Indonezji. W: Górak-Sosnowska, K. red. Queer a islam. Alternatywna seksualność w kulturze muzułmańskiej. Sopot: Smak Słowa, ss. 132-135.

Jąderek, I. 2016. Rozwój tożsamości płciowej i specyfika wsparcia szkolnego dla transpłciowych dzieci i młodzieży. W: Dynarski, W., Jąderek, I. i Kłonkowska, A.M. red. Transptciowa młodzież w polskiej szkole. Raport z badań. Gdańsk: UG, ss. 11-20.

Karlsson, G. 2015. Męskość jako projekt: kilka uwag psychoanalitycznych. Teksty Drugie. 2, ss. 381-407.

Lambda Legal, Human Rights Campaign, Hogan Lovells, i New York City Bar. 2016. Creating equal access to quality health care for transgender pa- 
tients. Transgender-affirming hospital policies. New York, Washington: Human Rights Campaign Foundation.

Le, V., Arayasirikul, S., Chen, Y.H., Jin, H. and Wilson, E.C. 2016. Types of social support and parental acceptance among transfemale youth and their impact on mental health, sexual debut, history of sex work and condomless anal intercourse. The Journal of the International AIDS Society. 19, (3 Suppl 2): 20781. https://www.ncbi.nlm.nih.gov/pmc/articles/ PMC4949317/ (16.07.2020).

Manson, J. 2008. Prenatal exposure to sex steroid hormones and behavioral/ cognitive outcomes. Metabolism. 57, pp. 16-21.

Mayer, L. and McHugh, P. 2016. "Introduction," Sexuality and Gender: Findings from the Biological, Psychological, and Social Sciences. Special Report. The New Atlantis. 50, pp. 10-12.

Morton, J. 2008. Transgender Experiences in Scotland: Research Summary. Edinburgh: Transgender Alliance.

Mitchell, M. and Howarth, C. 2009. Trans research review, Equality and Human Rights Commission. Research report 27. Manchester: NatCen.

Nowak-Dziemianowicz, M. 2018. Koncepcje uznania w perspektywie pedagogiki ogólnej jako alternatywa wobec neoliberalnej wizji współczesnego świata. Forum Pedagogiczne. 1, ss. 167-182.

Park, A. 2016. Reachable: Data collection methods for sexual orientation and gender identity, United Nations Commission on the Status of Women. New York: The Williams Institute.

Powell, J. and Menendian, S. 2016. The Problem of Othering: Towards Inclusiveness and Belonging. Othering \& Belonging. Expanding the Circle of Human Concern. 1, pp. 14-40.

Puts, D., McDaniel, M., Jordan, C., and Breedlove, S.M. 2008. Spatial ability and prenatal androgens: meta-analyses of congenital adrenal hyperplasia and digit ratio (2D:4D) studies. Archives of Sexual Behavior. 37, pp. 100-111 .

Raport ECRI. 2015. Raport ECRI dotyczacy Polski (piąty cykl monitoringu). Strasbourg: Council of Europe F-67075. https://rm.coe.int/fifth-report-on-poland-polish-translation-/16808b59a2 (16.07.2020).

Riittakerttu, K., Bergman, H., Työläjärvi, M. and Frisén, L. 2018. Gender dysphoria in adolescence: current perspectives. Adolescent Health, Medicine and Therapeutics. 9, pp. 31-41.

Robertson, J. ed. 2005. Same-sex cultures and sexualities. An anthropological reader. Oxford: Blackwell. 
Siostrzonek-Sergiel, A. 2017. Zarządzanie różnorodnością a prawne problemy transseksualizmu. Przedsiębiorczość i Zarzqdzanie. XVIII (11), 2, ss. 251-265 .

Śledzińska-Simon, A. 2013. Sytuacja prawna osób w Polsce. W: Dynarski, W. i Śmiszek, K. red. Sytuacja prawna osób transptciowych w Polsce. Warszawa: Polskie Towarzystwo Prawa Antydyskryminacyjnego, ss. 149-180. The American Academy of Pediatrics. 2018. Caring for your School Aged Child: Ages 5-12. New York: Bantam.

United Nations Development Programme. 2016. Being LGBTI in China A National Survey on Social Attitudes towards Sexual Orientation, Gender Identity and Gender Expression. New York: United Nations Development Programme.

Whittle, S., Turner, L. and Al-Alami, M. 2007. Engendered Penalties: Transgender and Transsexual People's Experiences of Inequality and Discrimination. The Equalities Review. Wetherby: Communities and Local Government.

Wikan, U. 2013. Resonance: beyond the words. Chicago: University of Chicago Press.

Williams, S. 2018. Are the brains of transgender people different from those of cisgender people? The Scientist. 1 (3). https://www.the-scientist.com/ features/are-the-brains-of-transgender-people-different-from-those-of-cisgender-people-30027 (16.07.2020).

Winter, S., Diamond, M., Green, J., Karasic, D., Reed, T., Whittle, S. and Wylie, K. 2016. Transgender people: health at the margins of society. The Lancet. 388 (10042), pp. 390-400.

\section{Sociocultural mechanisms in the functioning of a transgender person}

Abstract: Due to the social intolerance of gender identity behaviors, most of the transgender people experience a serious stress at various stages of their lives. Aspects of the social relations are important for the dignified and friendly functioning of a transgender child at school and their school achievements and then - as an adult - their professional development and social relations. While some schools and work places offer safe spaces, many people are still experiencing negative, hostile and dangerous environments. Without specific measures to protect transgender people and disseminate the knowledge about transgender in society, most people with non-normative gender identity remain vulnerable to discrimi- 
nation, harassment and intimidation. That is why it is so important to diagnose difficulties in the social functioning of transgender people and to suggest solutions to improve their situation in the conditions of exclusion.

Keywords: sex identity, transgender, tolerance, discrimination, society, knowledge

Translated by Karolina Czerwiec 